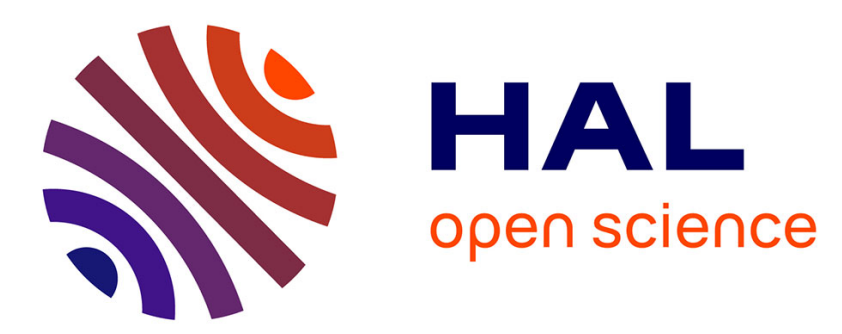

\title{
Investigations of exfoliating graphite intercalation compounds using time-resolved DEXAFS
}

\author{
T. Ressler, U. Hatje, S. Twumasi, K. Lochte, W. Metz
}

\section{To cite this version:}

T. Ressler, U. Hatje, S. Twumasi, K. Lochte, W. Metz. Investigations of exfoliating graphite intercalation compounds using time-resolved DEXAFS. Journal de Physique IV Proceedings, 1994, 04 (C9), pp.C9-167-C9-170. 10.1051/jp4:1994927 . jpa-00253488

\section{HAL Id: jpa-00253488 https://hal.science/jpa-00253488}

Submitted on 1 Jan 1994

HAL is a multi-disciplinary open access archive for the deposit and dissemination of scientific research documents, whether they are published or not. The documents may come from teaching and research institutions in France or abroad, or from public or private research centers.
L'archive ouverte pluridisciplinaire HAL, est destinée au dépôt et à la diffusion de documents scientifiques de niveau recherche, publiés ou non, émanant des établissements d'enseignement et de recherche français ou étrangers, des laboratoires publics ou privés. 


\title{
Investigations of exfoliating graphite intercalation compounds using time-resolved DEXAFS
}

\author{
T. Ressler, U. Hatje, S. Twumasi, K. Lochte and W. Metz \\ Institute of Physical Chemistry, University of Hamburg, Bundesstr. 45, 20146 Hamburg, Germany
}

\begin{abstract}
The exfoliation processes (rapid thermal decomposition) of $\mathrm{CuCl}_{2}$ graphite intercalation compounds (GICs) cointercalated with $\mathrm{FeCl}_{3}$ or $\mathrm{AlCl}_{3}$ were investigated using time resolved X-ray absorption spectroscopy in an energy dispersive mode. The experiments were carried out at the DEXAFS beam line at HASYLAB (Hamburg). The evolution of the absorption spectra of the $\mathrm{Cu} \mathrm{K}$-edge was compared with the reaction of pure $\mathrm{CuCl}_{2}$ under the same conditions. From the exfoliation of the $\mathrm{CuCl}_{2} / \mathrm{AlCl}_{3}-\mathrm{GIC}$ a $\mathrm{CuO}$ graphite compound can be obtained. The formation resembles the reaction of pure $\mathrm{CuCl}_{2}$, whereas the exfoliation of the $\mathrm{CuCl}_{2} / \mathrm{FeCl}_{3}$-GIC results in a mixture of $\mathrm{Cu}_{2} \mathrm{O}, \mathrm{CuO}$ and $\mathrm{Cu}$ clusters. The reduction of the $\mathrm{Cu}$ (II) at a reaction temperature of $500^{\circ} \mathrm{C}$ is correlated with an oxidation of $\mathrm{Fe}$ (II) to $\mathrm{Fe}$ (III).
\end{abstract}

\section{Introduction}

Graphite compounds with catalytic activity in heterogeneous catalysis could be obtained by exfoliation (rapid thermal decomposition) of graphite intercalation compounds (GICs) [1,2]. During this process, in which the GICs are heated up very fast, the structure of the GICs is partially destroyed and the inner surface increases. Starting with GICs of the acceptor type with transition metal chlorides the exfoliation in air can result in metal oxides of various oxidation states or highly dispersed metal clusters. GICs with intercalate layers consisting of more than one transition metal are supposed to show a different behaviour in the exfoliation process leading to graphite compounds with different properties. We report time resolved X-ray absorption spectroscopic (XAS) investigations of the evolution of different compounds during the exfoliation of cointercalated copper(II) chloride GICs compared to the reaction of $\mathrm{CuCl}_{2}$ in air.

\section{Experimental}

Two different $\mathrm{CuCl}_{2} \mathrm{GICs}$, cointercalated with $\mathrm{FeCl}_{3}$ or $\mathrm{AlCl}_{3}$, were investigated, a stage $2 \mathrm{CuCl}_{2} / \mathrm{AlCl}_{3}-\mathrm{GIC}$ and a stage $6 \mathrm{CuCl}_{2} / \mathrm{FeCl}_{3}$-GIC. Due to the preparation process of the GICs a residual content of water can not be excluded. Therefore a $\mathrm{CuCl}_{2} \cdot \mathrm{xH}_{2} \mathrm{O}$ compound instead of pure $\mathrm{CuCl}_{2}$ was chosen to compare with the intercalation compounds.

The $\mathrm{CuCl}_{2} / \mathrm{FeCl}_{3} \mathrm{GIC}$ and the $\mathrm{CuCl}_{2} / \mathrm{AlCl}_{3}$ GIC were prepared in sealed glass tubes containing a chlorine pressure of 0.5 bar at $350{ }^{\circ} \mathrm{C}$ and $200{ }^{\circ} \mathrm{C}$, respectively. The graphite flakes were ground, mixed with the same amount of $\mathrm{NaY}$ zeolite as a stabilising matrix, and pressed to a self supported wafer (thickness $1.3 \mathrm{~mm}$ ).

XAS experiments were carried out at the DEXAFS station at HASYLAB (Hamburg). The standard set-up for dispersive XAS was used [3] with a bent $\mathrm{Si}(111)$ monochromator crystal in reflection geometry and a cooled photo diode array as detector. The sample was installed in a flow-through reactor. The exfoliation was carried out in air in a temperature range of $30^{\circ} \mathrm{C}$ to $600^{\circ} \mathrm{C}$ and with a heating rate of $35 \% \mathrm{~min}$ to avoid the deintercalation of the metal chloride. Absorption spectra were taken every $6 \mathrm{~s}$ averaging 40 single spectra with an integration time of $120 \mathrm{~ms}$ each. Reference absorption spectra were measured at the EXAFS II and the RÖMO II beam line at HASYLAB. 


\section{Data analysis}

The dark signal of the detector, the $I_{0}$ signal without a sample and a metal foil were measured before and after the reaction for each experiment. During the reaction the 1024 photo diodes of the detector were read out continuously without any movement of the system components. To obtain a single absorption spectra the appropriate $\mathrm{I}_{0}$ was calculated from a linear interpolation between the two measured $\mathrm{I}_{0}$ signals.

The conversion from photo diodes to the photon energy was performed by applying a second order polynom on the data. The coefficients of the polynom were obtained from a computer supported comparison of the metal foil spectrum with a $\mathrm{Cu}$ metal reference spectrum.

The spectra were background corrected by an 1-order polynom and normalised to an edge jump equal one. The $\mathrm{E}_{0}$ value was chosen as the first inflection point of the absorption edge. The atomic absorption was calculated by fitting a third order polynom to the $\mathrm{k}$ weighted data. After that the extracted $\chi(\mathrm{k}){ }^{*} \mathrm{k}^{3}$ was multiplied by a KaiserBessel window and Fourier transformed (FT) to obtain the radial distribution function.

\section{Results}

The X-ray diffraction (XRD) diagram of the two GICs are shown in Fig. 1 together with the positions and theoretical intensities of the $00 \mathrm{~L}$ Bragg reflections for a stage 2 and a stage $6 \mathrm{CuCl}_{2}$ GIC. Due to the small difference in the scattering factor of $\mathrm{Cu}$ and $\mathrm{Fe}$ it is impossible to distinguish between them using a common structure refinement procedure. The non-appearance of superstructure peaks between the normal 00L Bragg reflections indicates the existence of a cointercalation. Therefore a mixture of $\mathrm{FeCl}_{3}$ and $\mathrm{CuCl}_{2}$ or $\mathrm{AlCl}_{3}$ and $\mathrm{CuCl}_{2}$ in the intercalate layer must be assumed, which can result in a chemical interaction between the different metals. In the case of the $\mathrm{Cu} / \mathrm{Fe}$-GIC the appearance of $\mathrm{Fe}$ (III) can be concluded from a comparison of the XANES region of the $\mathrm{Fe} \mathrm{K}$-edge of the $\mathrm{GIC}, \mathrm{FeCl}_{2}$, and $\mathrm{FeCl}_{3}$ (Fig. 4). Although the intercalation was carried out under chlorine atmosphere with $\mathrm{FeCl}_{3}$, the obtained intercalation compound seems to consist of a mixture of $\mathrm{FeCl}_{2}$ and $\mathrm{FeCl}_{3}$.
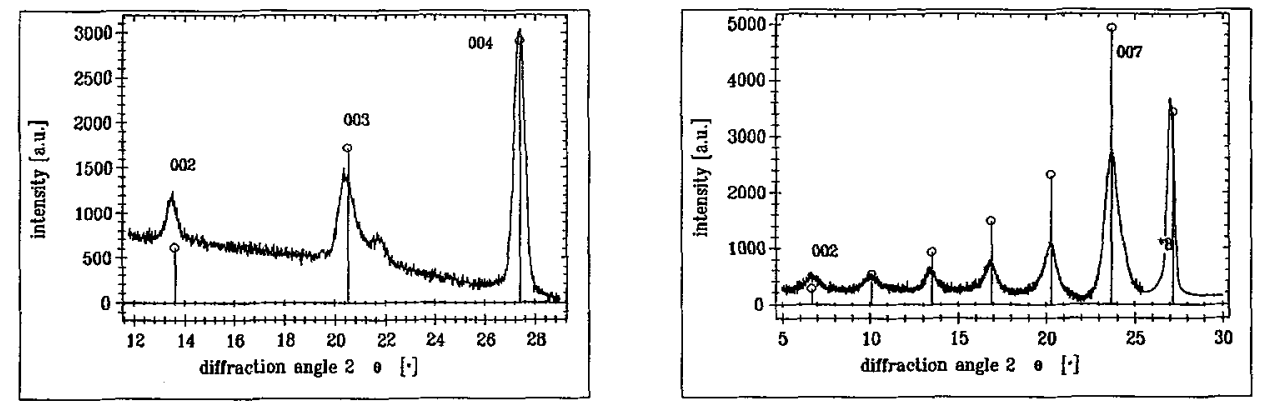

Fig. $1 \mathrm{XRD}$ of a stage $2 \mathrm{CuCl}_{2} / \mathrm{AlCl}_{3}$-GIC (left) and a stage $6 \mathrm{CuCl}_{2} / \mathrm{FeCl}_{3}$-GIC (right),

$00 \mathrm{~L}$ reflections. The lines show the calculated intensities and peak positions for an ideal

stage 2 (left) and stage 6 (right) $\mathrm{CuCl}_{2}$ GIC.

The XAS measurements were performed at the $\mathrm{Cu} \mathrm{K}$-edge and the $\mathrm{Fe} \mathrm{K}$-edge for the $\mathrm{Cu} / \mathrm{Fe}$-GIC. Fig.2 and 3 show the evolution of the absorption spectra of the $\mathrm{CuCl}_{2}$-GICs during the exfoliation and during the reaction of $\mathrm{CuCl}_{2}$ in air, respectively. The similar behaviour of the $\mathrm{Cu} / \mathrm{Al}$-GIC and pure $\mathrm{CuCl}_{2}$ can easily be seen (Fig.2), whereas the exfoliation of the $\mathrm{Cu} / \mathrm{Fe}$-GIC proceeds in two steps (Fig.3), leading to a different graphite compound. Fig.5 and 6 show the shift of the $\mathrm{Cu} \mathrm{K}$-edge in relation to the edge position of a $\mathrm{Cu}$ metal foil during the exfoliation. Whereas the edge shift of the $\mathrm{Cu} / \mathrm{Al}$-GIC and the pure $\mathrm{CuCl}_{2}$ differs only slightly, a large shift of the edge position for the $\mathrm{Cu} / \mathrm{Fe}$-GIC in a temperature range of $500^{\circ} \mathrm{C}-520^{\circ} \mathrm{C}$ can be observed. This edge shift indicates the reduction of $\mathrm{Cu}(\mathrm{II})$ to $\mathrm{Cu}(\mathrm{I})$ and is correlated to the oxidation of $\mathrm{Fe}$ (II) to $\mathrm{Fe}$ (III) in the same temperature range (Fig.6, right). Compared to the $\mathrm{CuCl}_{2}$ and the $\mathrm{Cu} / \mathrm{Al}$-GIC the copper in the $\mathrm{Cu} / \mathrm{Fe}$-GIC seems to be partially reduced, leading to a smaller edge shift relative to the $\mathrm{Cu}$ metal foil and a different XANES (Fig.3). The XANES of the Cu/Fe-GIC at room temperature resembles the XANES of the $\mathrm{Cu} / \mathrm{Al}-\mathrm{GIC}$ at $250^{\circ} \mathrm{C}$. 

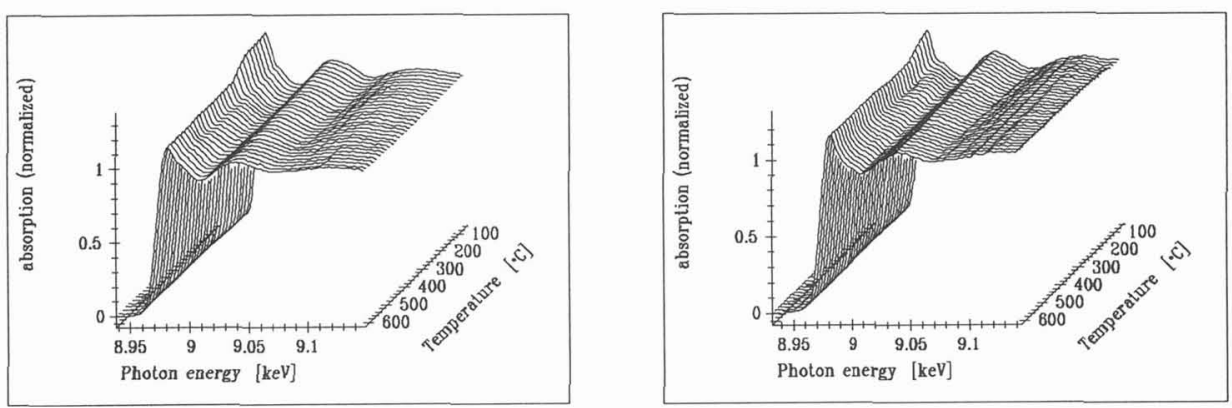

Fig.2 Evolution of the $\mathrm{Cu} \mathrm{K}$ near edge structure during the reaction of $\mathrm{CuCl}_{2}$ (left) and the exfoliation of $\mathrm{CuCl}_{2} / \mathrm{AlCl}_{3}$-GIC (right).

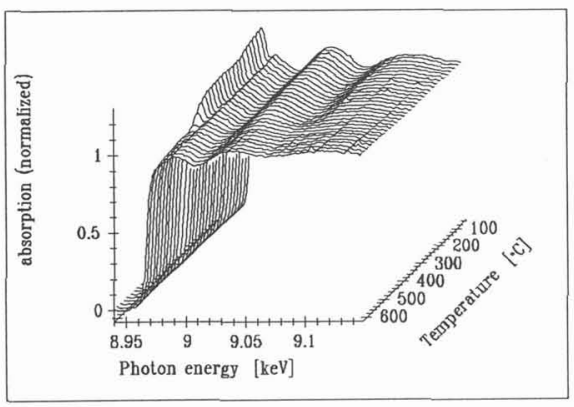

Fig. 3 Evolution of the $\mathrm{Cu} \mathrm{K}$ near edge structure during the exfoliation of the $\mathrm{CuCl}_{2} / \mathrm{FeCl}_{3}-\mathrm{GIC}$.

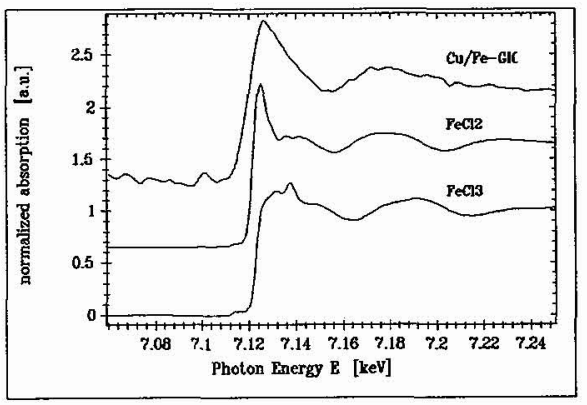

Fig.4 Normalised Fe $\mathrm{K}$ near edge structure of the $\mathrm{CuCl}_{2} / \mathrm{FeCl}_{3}$-GIC compared to absorption spectra of $\mathrm{FeCl}_{3}$ and $\mathrm{FeCl}_{2}$.
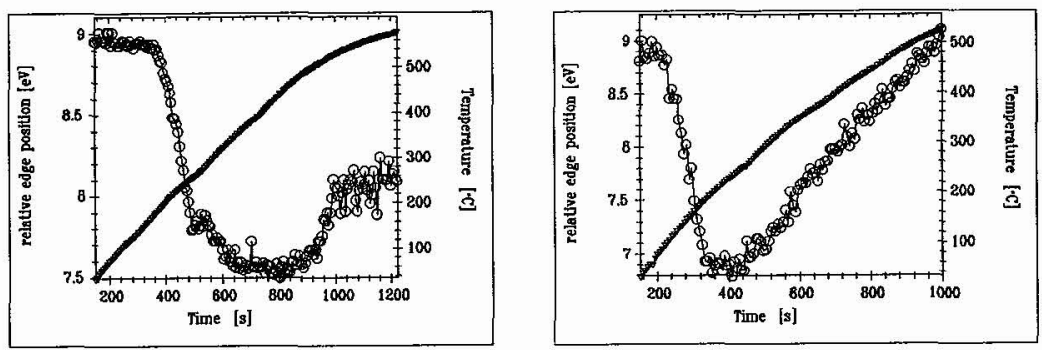

Fig.5 Change of the $\mathrm{Cu} \mathrm{K}$ edge position (circle) relative to the edge position of a $\mathrm{Cu}$ metal foil for

$\mathrm{CuCl}_{2}$ (left) and

$\mathrm{CuCl}_{2} / \mathrm{AlCl}_{3}$ - GIC (right) during the exfoliation.
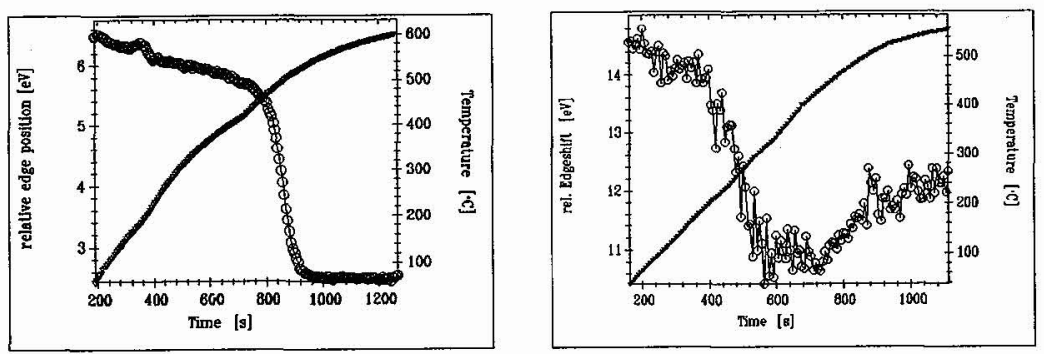

Fig.6 Change of the $\mathrm{Cu} \mathrm{K}$ edge position (circle) relative to the edge position of a $\mathrm{Cu}$ metal foil (left) and the Fe K-edge position relative to the edge position of a Fe metal foil (right) for the $\mathrm{CuCl}_{2} / \mathrm{FeCl}_{3}$ - $\mathrm{GIC}$ during the exfoliation. 
The reduction of $\mathrm{Cu}$ (II) to $\mathrm{Cu}(\mathrm{I})$ in the $\mathrm{Cu} / \mathrm{Fe}$ compound turned out to be reversible. After three days at room temperature in air the $\mathrm{Cu}(\mathrm{I})$ was reoxidised to $\mathrm{Cu}(\mathrm{II})$ and the reaction could be carried out again including the reduction of $\mathrm{Cu}$ (II) to $\mathrm{Cu}$ (I) at $500^{\circ} \mathrm{C}$ correlated to an oxidation of $\mathrm{Fe}$ (III) to $\mathrm{Fe}$ (III).

Fig.7 and 8 show the evolution of the $F T\left(\chi(k)^{*} k^{3}\right)$ at different reaction temperatures. A shift of the first shell around the copper atom to a smaller distance, due to the reaction of $\mathrm{CuCl}_{2}$ to copper oxide, can be observed in all three cases. For the reaction of $\mathrm{CuCl}_{2}$ and the exfoliation of the $\mathrm{Cu} / \mathrm{Al}-\mathrm{GIC}$ the FTs indicate the loss of residual water in a temperature range between $120^{\circ} \mathrm{C}$ and $180^{\circ} \mathrm{C}$. For the exfoliation of the $\mathrm{Cu} / \mathrm{Fe}-\mathrm{GIC}$ the first shell is slightly shifted to a higher distance, compared to the first shell of the product of the reaction of $\mathrm{CuCl}_{2}$. Additionally, a decreased coordination number of the first shell can be seen from Fig.8. Together with the large shift in the edge position to lower photon energy (Fig.6) this points out to a mixture of $\mathrm{CuO}, \mathrm{Cu}_{2} \mathrm{O}$, and $\mathrm{Cu}$ clusters.
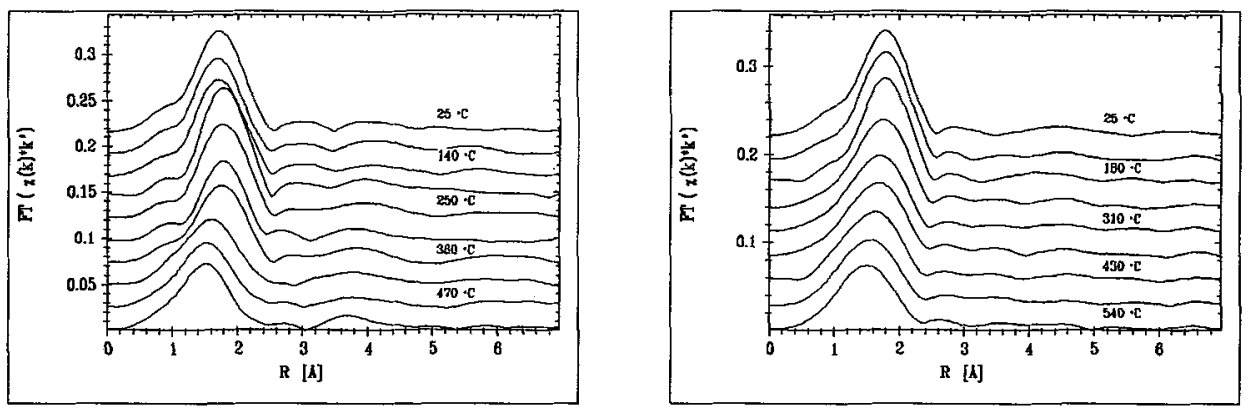

Fig. 7 Fourier transformed $\chi(\mathrm{k})^{*} \mathrm{k}^{3}$ of the $\mathrm{Cu} \mathrm{K}$-edge of $\mathrm{CuCl}_{2}$ (left) and the $\mathrm{CuCl}_{2} / \mathrm{AlCl}_{3}$-GIC (right) at different reaction temperatures.

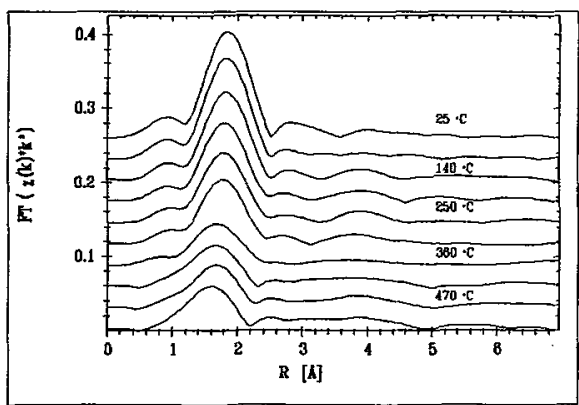

Fig. 8 Fourier transformed $\chi(k) * k^{3}$ of the $\mathrm{Cu}$ K-edge of the $\mathrm{CuCl}_{2} / \mathrm{FeCl}_{3}$ - $\mathrm{GIC}$ at different reaction temperatures.

\section{Conclusion}

The exfoliation of two cointercalated GICs $\left(\mathrm{CuCl}_{2} / \mathrm{AlCl}_{3}-\mathrm{GIC}\right.$ and $\mathrm{CuCl}_{2} / \mathrm{FeCl}_{3}$-GIC) were compared with the reaction of pure $\mathrm{CuCl}_{2}$ in air. At a temperature of $350{ }^{\circ} \mathrm{C}$ the copper(II) chloride in the $\mathrm{Cu} / \mathrm{Al}$-GIC reacts to copper(II) oxide, whereas the reaction of the pure $\mathrm{CuCl}_{2}$ starts at a temperature of $430^{\circ} \mathrm{C}$. The exfoliation of the $\mathrm{Cu} / \mathrm{Fe}$-GIC results in a mixture of copper(II) oxide, copper(I) oxide and copper clusters. The reduction of the copper(II) is correlated with an oxidation of the $\mathrm{Fe}$ (II) and turned out to be reversible at room temperature.

Financial support by the Bundesministerium fur Forschung und Technologie (project no.: 05 5GUFAB 8) is gratefully acknowledged.

\section{References :}

[1] G. Sirokman et al., Carbon, 26, 35 (1990)

[2] H.-P. Eickhoff, Dissertation, Hamburg 1993

[3] M. Hagelstein, S. Cunis, R. Frahm, W. Niemann, P. Rabe, Physica B, 158, 324 (1990) 